Check for updates

The BMJ

Cite this as: BMJ 2021;372:n673 http://dx.doi.org/10.1136/bmj.n673 Published: 11 March 2021

\title{
At the end of the covid-19 storm, another one is brewing
}

\section{Kamran Abbasi executive editor}

Something's coming, around the corner. With vaccine delivery progressing apace, encouraging efficacy data, cases and deaths now declining, and a third booster dose likely in August and September, ${ }^{12}$ some leaders are receiving positive media attention and a boost in the polls. The worst is over-possibly-for covid-19 in the UK, at least. But how long will this good feeling last?

What happens next is the question nobody can clearly answer, but if the growing anger, hurt, and exhaustion in the voices of health professionals are any indication, then trouble is brewing. ${ }^{3}$ Health services were already stretched when the pandemic began. The morale of staff was low, exacerbating a workforce crisis. Baseline population health was reflected in slowed gains in life expectancy.

Now health professionals will be left to cope with a backlog of delayed care, ${ }^{4}$ declines in morale and mental health, ${ }^{5}$ workforce problems made worse by Brexit and concerns over pensions, ${ }^{6}$ deepening inequalities and disenfranchised minorities, ${ }^{7}$ and dismay over a budget that disinvests in public services and ignores social care. ${ }^{8}$

A deep sense of service has driven staff, the reason why many become healers, a purpose that is too often lost in the blood, sweat, and tears of meeting the expectations of patient care in a world of unlimited demand. That motivation was first tested by a crisis in personal protective equipment. While staff wore bin bags, risking their lives and those of patients, the government stockpiled tens of millions of unusable items made by unsuitable companies, and then, according to the High Court, failed to meet its legal obligation to publish the lucrative contracts for scrutiny within 30 days. ${ }^{9}$

The countries of East Asia, and some in the Middle East and Africa, prepared and responded better than the rest of the world. ${ }^{10}$ They even shared their lessons from previous pandemics far and wide. There were no secrets, from border controls to personal protective equipment, the balance between central control and local provision, and the implementation of test, trace, isolate, and support strategies.

And the last of these is the greatest indictment of UK government policy. When a €37bn (€43bn; \$51bn) scheme stumbles in every area, ignoring sound experience and loud advice on how to do it well; when it makes no difference to the pandemic response, according to a report from the public accounts committee, ${ }^{11}$ contributing to avoidable deaths and illness; and when its failings are roundly ignored and denied by those running it, you begin to understand why health staff, many of whom are lower paid, have no time for insincere claps of encouragement by ministers or the $1 \%$ proposed pay rise that symbolises how their sacrifices are valued $(\mathrm{p} 384)^{12}$

How long can the goodwill of health professionals be taken for granted? Something's coming, and it probably isn't something good.

1 Mahase E. Covid-19: Booster dose will be needed in autumn to avoid winter surge, says government adviser. BM/2021:372:n664 doi: 10.1136/bmi.n664 pmid: 33687925

2 lacobucci G. Covid-19: Single dose of Pfizer and Oxford vaccines cuts risk of hospital admission by $80 \%$ in over 80 s, data suggest. BMJ 2021;372:n612. doi: 10.1136/bmj.n612 pmid: 33653737

3 Salisbury H. Helen Salisbury: Dealing with covid trauma and grief. BM 2021;372:n649. doi: 10.1136/bmj.n649 pmid: 33687946

4 Copeland C, Greenbrook S. The mental strain of covid-19 never really abates-HCWs' experiences of the covid-19 pandemic. https://blogs.bmi.com/bmi/2021/03/01/the-mental-strain-of-covid-19never-really-abates-hcws-experiences-of-the-covid-19-pandemic

5 Mathew R. Rammya Mathew: Workforce must be at the centre of covid-19 recovery plans. BMJ 2021;372:n635 doi: 10.1136/bmi.n635 pmid: 33687989

6 Rimmer A. NHS pensions: what do changes to the lifetime allowance mean?BMJ 2021;372:n660. doi: 10.1136/bmj.n660 pmid: 33687980

7 Razai MS, Osama T, McKechnie DGJ, Majeed A. Covid-19 vaccine hesitancy among ethnic minority groups. BM/2021;372:n513. doi: 10.1136/bmj.n513 pmid: 33637577

8 Cowper A. Andy Cowper: The Budget? Fudge it. 5 Mar 2021 https://blogs.bmj.com/bmj/2021/03/05/andy-cowper-the-budget-fudge-

9 McKee $M$. The UK's PPE procurement scandal reminds us why we need ways to hold ministers to account. BM/2021;372:n639. doi: 10.1136/bmi.n639 pmid: 33685915

10 Chua AQ Al Knawy B, Grant B, etal. How the lessons of previous epidemics helped successful countries fight covid-19. BMJ2021;372:n486.

11 Wise I.Covid-19: NHS Test and Trace made no difference to the pandemic says report. BMJ2021;372:n663. doi: 10.1136/bmj.n663 pmid: 33687919

12 Rimmer A. Doctors unhappy at proposed $1 \%$ pay rise for consultants and salaried GPs in England. BMJ2021;372:n646. 